\title{
IN VITRO ANTIUROLITHIATIC ACTIVITY OF KALYANA KSHARAM - A HERBO MINERAL FORMULATION
}

\author{
PADMAPRIYA. $\mathbf{G}^{\mathbf{1}}$, VIMALAVATHINI. $\mathbf{R}^{2}$ \& KAVIMANI. $\mathrm{S}^{\mathbf{3}}$ \\ ${ }^{1,3}$ Department of Pharmacology, College of Pharmacy, Mother Theresa Post Graduate and \\ Research Institute of Health Sciences, Puducherry, India \\ ${ }^{2}$ Assistant Professor, Department of Pharmacology, College of Pharmacy, Mother Theresa Post Graduate and \\ Research Institute of Health Sciences, Puducherry, India
}

ABSTRACT
PURPOSE
To evaluate the in vitro antiurolithiatic activity of Kalyana Ksharam (KK).
MATERIALS AND METHODS
Inhibition of calcium oxalate (CaOx) crystal formation by KK was investigated by four different methods, namely,
nucleation, aggregation, artificial urine and dissolution method. In nucleation, aggregation and artificial urine assay, the
effectiveness of KK at different concentration (100, 200, $400,600,800$ and 1000 $\mu g / m l)$ on CaOx crystallization in vitro
was evaluated, while in dissolution method the percentage of dissolution of CaOx crystals was investigated.
RESULTS
KK was effective in inhibiting CaOx crystals in dose-dependent manner and was comparable to that of cystone.
CONCLUSIONS
The present study suggests that KK has potential effect on in vitro inhibition of CaOx crystals.
KEYWORDS: Calcium oxalate, Kalyana Ksharam, Urolithiasis \& Crystallization

Received: Jul 03, 2019; Accepted: Jul 23, 2019; Published: Sep 19, 2019; Paper Id.: IJMPSOCT20192

\section{INTRODUCTION}

Urolithiasis is the common disease of the urinary tract and may be formed in any part of the urinary system ${ }^{1}$. It affects $12 \%$ of population, with a reappearance rate of $70-80 \%$ in male and $47-60 \%$ in female ${ }^{2}$. Calcium oxalate $(\mathrm{CaOx})$ exists in two crystal forms such as $78 \%$ of calcium oxalate monohydrate (COM) and $43 \%$ of calcium oxalate dihydrate (COD) ${ }^{1}$. For crystallization, the impelling cause is the decline of potential energy of molecules binding to each other ${ }^{3}$. Gone are days when mankind was looking towards modernization and westernization. Though allopathic drugs are effective in acute situation on chronic use, it exhibits severe adverse effects. A frightening rise in the occurrence of urolithiasis tied with the motivation given by WHO created a need to exploit traditional system of medicines ${ }^{4}$. One such is the ayurvedic formulation Kalyana Ksharm (KK), that is clinically used in the management of urinary calculi. It is prepared by mixing an appropriate concentration of Suthi (Zingiberofficinale), Maricha (Piper nigrum), Pippali (Piper longum), Saindhava (Rock salt), Vidalavana (Sal ammoniac), Samudralavana (Sea salt), Hartaki (Terminalia chebula), Amalaki (Phyllanthusemblica), Vibhitaki (Terminalia bellirica), Danti (Baliospermummontanum), Arushkara 
(Semecarpusanacardium), Chitraka (Plumbagozeylanica), Gomutram (cow's urine) and Eranda (Ricinuscommunis). Clinically, it is used to alleviate in urinary tract infection, dysuria, constipation, bloating, hemorrhoids, sprue, intestinal worm infestation, cough, cold, bronchitis, and asthma. Though being clinically used in ayurveda still no scientific evidence for antiurolithiatic activity of KK has been established. Hence, the study is to document the in vitro antiurolithiatic activity of KK by four in vitro methods.

\section{MATERIAL AND METHODS}

Chemicals: Cystone was procured from Himalaya Drug Company, Karnataka, India and KK was procured from Kottakkal Arya Vaidyasala, Kerala. Calcium chloride, sodium oxalate, Tris buffer, sodium chloride, sodium phosphate, sodium citrate, magnesium sulphate, sodium sulphate, potassium chloride, ammonium hydroxide, ammonium chloride, sulphuric acid, ammonia, hydrochloric acid, potassium permanganate were procured from Merck Specialities Private Limited, Mumbai.

Apparatus: UV Spectrophotometer - Thermos Fisher Scientific, Great Britan

\section{Nucleation Assay}

About $5 \mathrm{mmol} / \mathrm{L}$ and $7.5 \mathrm{mmol} / \mathrm{L}$ of calcium chloride and sodium oxalate solutions were prepared in a buffer with a $\mathrm{pH}$ of 6.5 containing Tris $0.05 \mathrm{mmol} / \mathrm{L}$ and $\mathrm{NaCl} 0.15 \mathrm{~mol} / \mathrm{L}$, respectively. Solution of calcium chloride was mixed with $\mathrm{KK}$ and cystone (standard) in a concentration of 100, 200, 400, 600, 800 and $1000 \mu \mathrm{g} / \mathrm{ml}$. About $950 \mu \mathrm{l}$ of sodium oxalate solution was added to initiate the crystal formation. Final solutions were incubated for $30 \mathrm{~min}$ at $37^{\circ} \mathrm{C}$. The absorbance was taken at $620 \mathrm{~nm}$. The rate of nucleation was estimated by comparing the induction time in the presence of the KK and cystone with that of control $^{5}$. The percentage inhibition of $\mathrm{CaOx}$ crystal formation was calculated ${ }^{6}$.

\section{Aggregation Assay}

Calcium chloride and sodium oxalate at $50 \mathrm{mmol} / \mathrm{L}$ concentration were mixed to form COM crystals. Solution were equilibrated to $60^{\circ} \mathrm{C}$ for $1 \mathrm{~h}$ and cooled to $37^{\circ} \mathrm{C}$ and then evaporated. The formed COM crystals are added to the solution containing Tris $0.05 \mathrm{~mol} / \mathrm{L}$ and $\mathrm{NaCl} 0.15 \mathrm{~mol} / \mathrm{L}$ at $\mathrm{pH} 6.5$. KK and cystone in the concentration of 100, 200, 400, 600, 800 and $1000 \mu \mathrm{g} / \mathrm{ml}$ were added to the solution. The absorbance at $620 \mathrm{~nm}$ was recorded at 30, 60, 90, 180 and $360 \mathrm{~min}^{7}$. The percentage inhibition of $\mathrm{CaOx}$ crystal formation was calculated ${ }^{6}$.

\section{IN VITRO Crystallization using Artificial Human Urine}

Preparation of artificial urine: The artificial urine (AU) was prepared at $\mathrm{pH} 6.0$ in a composition containing calcium chloride $(4.5 \mathrm{mM})$, sodium phosphate $(32.3 \mathrm{mM})$, magnesium sulfate $(3.85 \mathrm{mM})$, sodium citrate $(3.21 \mathrm{mM})$, sodium sulfate $(16.95 \mathrm{mM})$, sodium chloride $(105.5 \mathrm{mM})$, ammonium hydroxide $(17.9 \mathrm{mM})$, potassium chloride $(63.7 \mathrm{mM})$, sodium oxalate $(0.32 \mathrm{mM})$ and ammonium chloride $(0.0028 \mathrm{mM})$. One milliliter of AU was added to $0.5 \mathrm{ml}$ of distilled water to serve as a blank and $0.5 \mathrm{ml}$ of $0.01 \mathrm{M}$ sodium oxalate was added to it and measured in a period of $10 \mathrm{~min}$. KK and cystone at the concentration of $100,200,400,600,800$ and $1000 \mu \mathrm{g} / \mathrm{ml}$ were prepared. Each $0.5 \mathrm{ml}$ of $\mathrm{KK}$ was added to $1 \mathrm{ml}$ of $\mathrm{AU}$ to measure blank reading and then $0.5 \mathrm{ml}$ of $0.01 \mathrm{M}$ sodium oxalate solution was added and the absorbance at $620 \mathrm{~nm}$ were taken for a period of 10 mins. The percentage of inhibition of CaOx crystal formation was calculated $^{3}$. 


\section{Dissolution of Experimental Stone}

\section{Preparation of Experimental Kidney Stones (CaOx stones)}

Calcium oxalate is precipitated by mixing $1.47 \mathrm{~g}$ of calcium chloride dehydrate in $100 \mathrm{ml}$ of distilled water and $1.34 \mathrm{~g}$ of sodium oxalate in $100 \mathrm{ml}$ of $2 \mathrm{~N}$ sulphuric acid. The precipitate is freed of sulphuric acid by using ammonia. The precipitate is dried at $60^{\circ} \mathrm{C}$ for $2 \mathrm{~h}$ after washing with distilled water.

\section{Preparation of Semi-Permeable Membrane from Farm Eggs}

Empty eggs shell were taken by removing the entire content of egg and kept in a solution of 8 ml concentrated hydrochloric acid in $400 \mathrm{ml}$ distilled water for $48 \mathrm{~h}$ resulting in decalcification of semi-permeable membrane. The semipermeable membranes were removed after $48 \mathrm{~h}$ from the egg shells and placed in a solution of ammonia to neutralize. Semi permeable membranes were refrigerated at $\mathrm{pH} 7.2$ in the moistened condition.

\section{Estimation of Calcium Oxalate}

The following solutions were loaded in the semi-permeable membrane tied at one end by immersing in $0.1 \mathrm{M}$ Tris buffer.

Solution I: $2 \mathrm{ml}$ of $\mathrm{CaOx}(1 \mathrm{mg} / \mathrm{ml})+2 \mathrm{ml}$ of distilled water

Solution II: $2 \mathrm{ml}$ of $\mathrm{CaOx}(1 \mathrm{mg} / \mathrm{ml})+2 \mathrm{ml}$ of cystone solution $(10 \mathrm{mg} / \mathrm{ml}, 20 \mathrm{mg} / \mathrm{ml}, 40 \mathrm{mg} / \mathrm{ml})$

Solution III: $2 \mathrm{ml}$ of $\mathrm{CaOx}(1 \mathrm{mg} / \mathrm{ml})+2 \mathrm{ml}$ of $\mathrm{KK}(10 \mathrm{mg} / \mathrm{ml}, 20 \mathrm{mg} / \mathrm{ml}, 40 \mathrm{mg} / \mathrm{ml})$

Other end is knotted to the mouth of the container with a stick and incubated for 3 days after heating at $37^{\circ} \mathrm{C}$ for 4h. Each solution is removed from the semi-permeable membrane after 3 days. Four milliliter of $1 \mathrm{~N}$ sulphuric acid and 60 $80 \mu \mathrm{l}$ of $0.02 \mathrm{M}$ potassium permanganate were added to the each solution and kept for 2 hours and the absorbance was taken at $620 \mathrm{~nm}^{8}$.

\section{RESULTS}

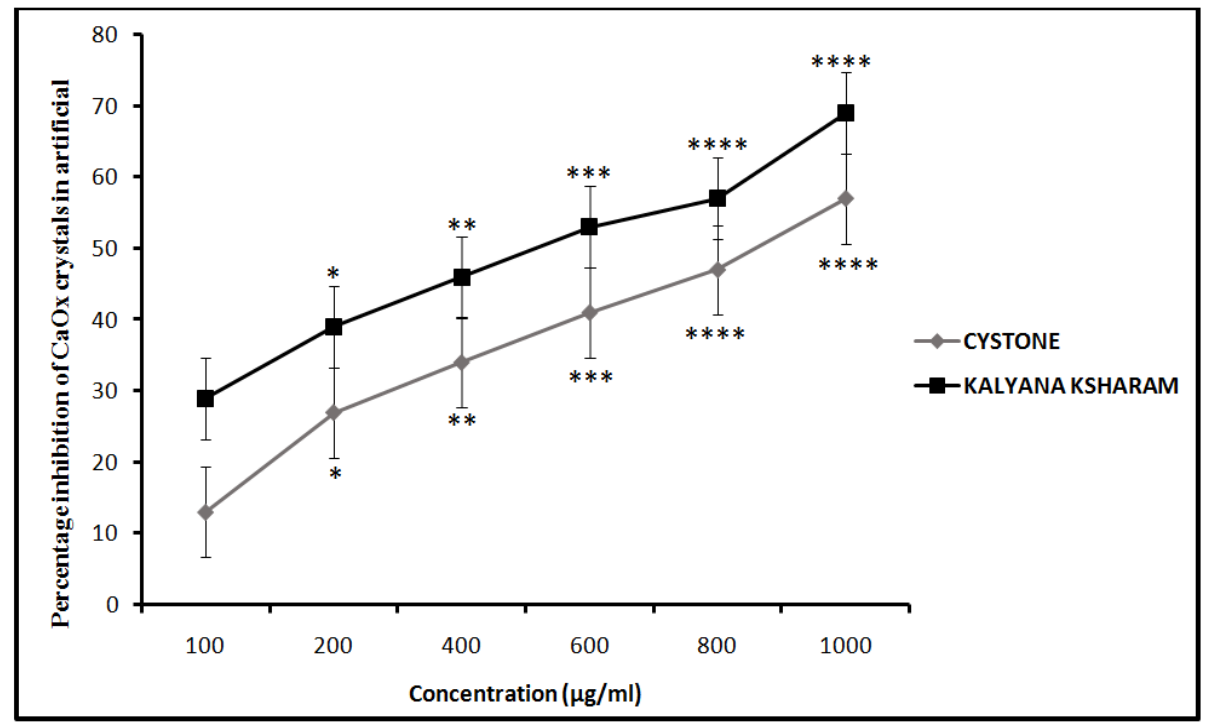

Figure 1: Percentage Inhibition of CaOx Crystals by Cystone and KK using Artificial Human Urine Assay. 


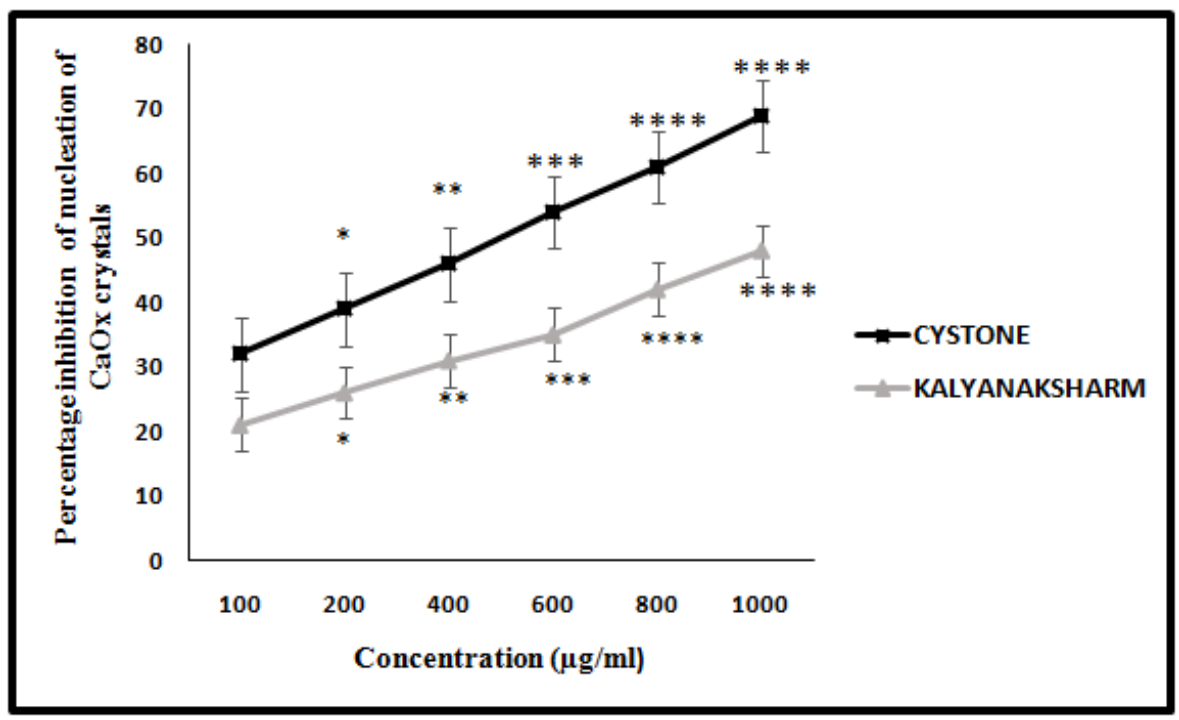

Figure 2: Percentage Inhibition of CaOx crystals by Cystone and KK for Nucleation Assay.

Data were expressed as mean \pm SEM $(\mathrm{n}=2)$. ${ }^{*} \mathrm{p}<0.05, * * \mathrm{p}<0.01, * * * \mathrm{p}<0.001, * * * * \mathrm{p}<0.0001$ against $100 \mu \mathrm{g} / \mathrm{ml}$ concentration using Student t-test.

There was no significant difference (Figure 1) between the percentage inhibition of $\mathrm{CaOx}$ crystallization at various concentration of cystone and $\mathrm{KK}$ and the percentage inhibition increases in dose dependent manner with $100 \mu \mathrm{g} / \mathrm{ml}$. The study showed that KK had more percentage inhibition of crystallization in artificial urine than cystone.

Data were expressed as mean $\pm \operatorname{SEM}(n=2) . * p<0.05, * * p<0.01, * * * p<0.001, * * * * p<0.0001 \mathrm{vs} \quad 100 \mu \mathrm{g} / \mathrm{ml}$ concentration using Student t-test.

Figure 2 shows the percentage inhibition of nucleation of $\mathrm{CaOx}$ crystals with various concentrations of $\mathrm{KK}$ and cystone. There was significant difference in percentage inhibition of cystone and KK at 600,800 and $1000 \mu \mathrm{g} / \mathrm{ml}$ indicating that cystone had better significant inhibition of nucleation than KK and percentage inhibition increases with $100 \mu \mathrm{g} / \mathrm{ml}$ in a dose dependent manner for both the drugs.

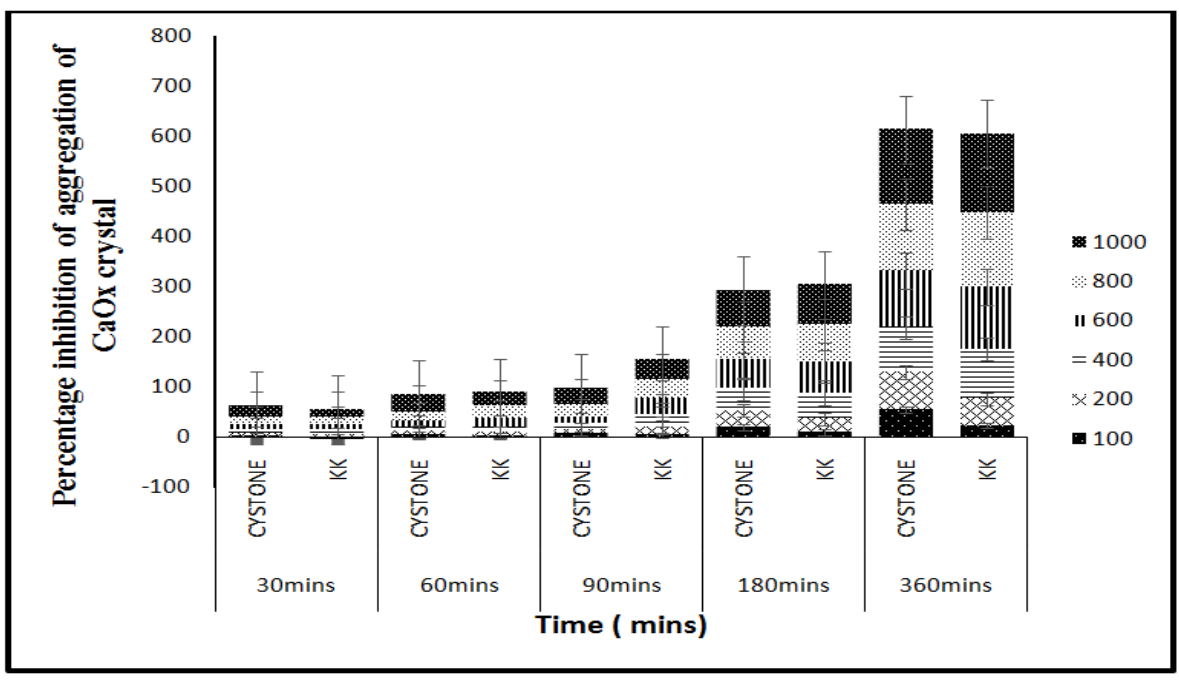

Figure 3: Percentage Inhibition of CaOx Crystals by Cystone and KK for Aggregation Assay. 


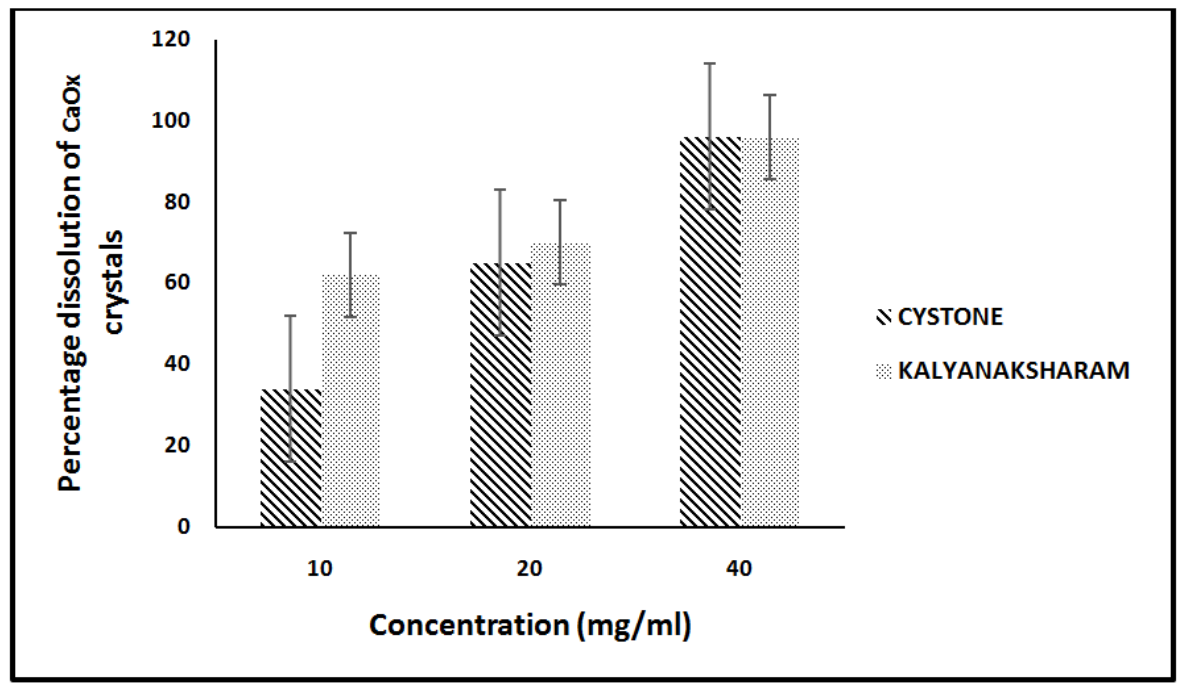

Figure 4: Percentage Dissolution of CaOx Crystals by Cystone and KK for Dissolution Method.

Data were expressed as mean \pm SEM $(n=2)$. Groups were compared using Student t-test.

There was no significant difference (Figure 3) in the percentage inhibition of aggregation of CaOx crystals at various concentrations of both drugs and there were comparable increases in percentage inhibition of $\mathrm{CaOx}$ in a dose dependent manner for both the drugs.

Data were expressed as mean \pm SEM $(n=2)$. Groups were compared using Student t-test.

There was a significant difference in percentage dissolution of $\mathrm{CaOx}$ crystals for cystone and $\mathrm{KK}$ at increasing doses (Figure 4). Also, KK exhibited higher percentage of dissolution than cystone in its lower concentration but at its highest concentration both exhibited equal percent of dissolution.

\section{DISCUSSIONS}

Urolithiasis includes supersaturation, nucleation, aggregation, growth and retention of crystals in the renal tubules ${ }^{5}$ In this dissertation work, the properties of KK were explored against kidney stone by in vitro.

Artificial human urine assay was used to study the supersaturation in growth of CaOx crystals. Normal human urine is dynamic, because new solutes are added or detached so the artificial urine method is considered ${ }^{7}$. The result from the study shows that KK had more percentage inhibition of crystallization in artificial urine (Figure 1) than cystone but was not statistically significant.

Crystalluria and stone formation is from heterogeneous nucleation induced by crystallization promoters ${ }^{10}$. Cystone exhibited better inhibition of nucleation than KK at various concentrations and was statistically significant. There was a significant difference in percentage inhibition of cystone and $\mathrm{KK}$ at 600,800 and $1000 \mu \mathrm{g} / \mathrm{ml}$ (Figure 2) indicating cystone had better significant inhibition of nucleation than KK.

Once stone formed, the crystalline particles aggregate to form larger particles. Aggregation of particles in solution is a balance of aggregating effects and disaggregation effects ${ }^{11}$. There was no significant difference (Figure 3 ) in the percentage inhibition of aggregation of $\mathrm{CaOx}$ crystals at various concentrations between the two drugs. 
KK has a higher percentage of dissolution than cystone even in its lower doses, but was not statistically significant. Also, KK exhibited higher percentage of dissolution (Figure 4) than cystone in its lower concentration, but in its higher concentration there was no much difference in percentage dissolution between them. Thus, our study shows that KK has significant antiurolithiatic activity based on in vitro test.

KK has phytoconstituents such as tannins, terpenoids, saponins, flavonoid and phenolic compounds. Tannin presents in Piper nigrum, Piper longum, Terminalia chebula, Terminalia belleria, Zingiber officinale, Emblical officinale, Plumbago zeylanica, Baliospermum montanum, Semecarpus anacardium, ingredients of KK which might have contributed to the inhibition of calcium oxalate crystals formation and dissolution of formed crystals in semi permeable membrane dissolution test. Flavonoids present in Baliospermum montanum, Semecarpus anacardium, Ricinus communis, Terminalia chebula, Terminalia belleria, Zingiber officinale, Piper nigrum, ingredients of KK and possess CaOx crystal dissolution potency and antioxidant activity ${ }^{6}$.

The ingredients of KK such as Piper nigrum, Piper longum, Zingiber officinale, Baliospermum montanum, Ricinus communis, Semecarpus anacardium containing saponins have antilithic properties and fragment mucoproteins in stone matrix ${ }^{6}$. Terpenoids present in Piper nigrum, Piper longum, Terminalia chebula, Zingiber officinale, Plumbago zeylanica, Baliospermum montanum, Semecarpus anacardium, ingredients of KK have been found to inhibit the cytotoxicity induced by calcium oxalate, they are also know to normalize the excretion of stone forming constituents ${ }^{9}$. Phenolic constituents in KK such as Zingiber officinale, Piper nigrum, Emblical officinale, Baliospermum montanum, Semecarpus anacardium exhibit antioxidant activity and prevent the crystal adhesion. ${ }^{12}$. Therefore, the anti-nucleation, anti-aggregatory and crystal growth defying activity of KK would have been an outcome of these phytoconstituents present in KK such as tannins, terpenoids, saponins, flavonoid and phenolic compounds.

Percentage inhibition of both drugs increased in a dose dependent manner for nucleation, aggregation, in vitro crystallization in artificial urine and dissolution methods. KK has more significant effect at higher doses in inhibiting supersaturation, however, the percentage inhibition of aggregation, nucleation and percentage dissolution was comparable with cystone. Ingredients of both cystone and KK were entirely different. Cystone is given at the dose of 4 tablets per day (each tablet contains $446 \mathrm{mg}$ based on the label claim) for treatment until stone passes out and 2 tablets per day after surgery for 2-3 months to prevent the recurrence of urolithiasis. But based on the case study, KK is prescribed at $500 \mathrm{mg}$ a day for 15 days $^{13}$. Thus, even at lower strength and shorter duration of treatment KK seems to be cost effect and better choice for the treatment of urolithiasis.

\section{CONCLUSIONS}

This study has given primary evidence for KK possessing antiurolithiatic property in vitro.

\section{REFERENCES}

1. Agarwal K, Varma R. Ocimumgratissimum L.: A Medicinal Plant with Promising Antiurolithiatic Activity. International Journal of Pharmaceutical Sciences and Drug Research 2014;6(1):78-81.

2. Sharma D, Dey YN, Sikarwar I, Sijoria R, Wanjari MM, Jadhav AD. In-Vitro study of aqueous leaf extract of Chenopodium album for inhibition of calcium oxalate and brushite crystallization. Egyptian Journal of Basic and Applied Sciences 2016;3:164-171. 
3. Srinivasa AKB, Kuruba L, Khan S, Saran GS. Antiurolithiatic Acitivity of GokhsuradiChuran, an Ayurvedic Formulation by In-Vitro Method. Advanced Pharmaceutical Bulletin 2013;3(2):477-79.

4. Chakradhar KV. A Comparative Clinical study on Renal calculi- An Ayurvedic Perspective. Journal of Dental and Medical Sciences 2012:5(2):21-32.

5. Sasikala V, Radha SR, Vijayakumari B. In-Vitro evaluation of RotulaaquaticaLour. For antiurolithiatic activity. Journal of Pharmacy Research 2013;6:378-82.

6. Bawari S, Sah AN, Tewari D. Antiurolithiatic Activity of Daucuscarota : An in vitro study. Pharmacognosy Journal 2018;10(5):880-4. doi:10.5530/pj.2018.5.148

7. Saha S, Verma RJ. Inhibition of calcium oxalate crystallization In-Vitro by an extract of Bergenia ciliate. Arab Journal of Urology 2013;11:187-92.

8. Patel, R. N. Comparision of Antagonistic Effects of the Endophytic Fungi and Trichoderma Species against Soybean Charcoal Rot Disease under Greenhouse Conditions.

9. Phatak RS, Hendre AS. In-vitro Antiurolithiatic Activity of Kalanchoepinnata Extract. International Journal of Pharmacognosy and Phytochemical Research 2015;7(2):275-79.

10. Barros ME, Lima R, Mercuri LP, Matos JR, Schor N, Boim MA. Effect of extract of Phyllanthusnirurion crystal deposition in experimental urolithiasis. Urological Research 2006:1-8. doi:10.1007/s00240-006-0065-1

11. Chhiber N, Sharma M, Kaur T, Singla S. Mineralization in health and mechanism of kidney stone formation. International Journal o Pharmaceutical Science Invention2014; 3:25-31.

12. Habeeb, A. D., MEA'AD, K. H., \& Ahmed, B. A. A. H. (2015). Psychosocial impact of sickle cell disease on families in Basra, Southern Iraq; An experience of caregivers. International Journal of Medicine and Pharmaceutical Sciences (IJMPS) ISSN $(P), 5(4), 41-52$.

13. Basavaraj DR, Biyani CS, Browning AJ, Cartledge JJ. The Role of Urinary Kidney Stone Inhibition and Promoters in the Pathogenesis of Calcium Containing Renal Stones. European Associate of Urology 2007;5:126-36.

14. Mandal B, Mandan S, Ahmad S. In vitro Inhibition of Calcium Oxalate Nucleation by Extract-based Fractions of Aerial Parts and Roots of Aervalanata (Linn.) Juss. exSchult. Indian Journal of Pharmaceutical Sciences 2013:79(6):957-64. doi:10.4172/pharmaceutical-sciences. 1000313

15. Purnima R, Smriti C, Rani VS, Balendra S. A Case Study on Mutrashmari(Urolithiasis) Using Kalyana Ksharam. World Journal of Pharmacy and Pharmaceutical Sciences 2017; 6(6):1668-76.

16. Manzoor, M., Shah, G. N., Mathivanan, V., MIR, G., \& Dar, S. A. Estimation of Mineral Contents of APIS Cerana Indica, APIS Dorsata and APIS Mellifera Honey from Plains, Hills and Western Ghats of Tamil Nadu and Jammu \& Kashmir.

\section{AUTHOR PROFILE}

G. Padmapriya completed M.Pharm( Pharmacology )and currently working as a lecturer in Mohamed Sathak AJ college of Pharmacy

Dr. R. Vimalavathini completed M.pharm,PhD ( Pharmacology) and done 23 publications and currently working as a Associate professor in Mother Teresa Post Graduate and Research Institute of Health sciences. Also, Member of Indian Pharmacological society. 
Prof. Dr. S. Kavimani Completed M.pharm,PhD ( Pharmacology) and has 200 publications and currently working as a Head of Pharmacology department in Mother Teresa Post Graduate and Research Institute of Health sciences. Also, Member of PCI, Elected member of PPC 